\title{
Production of a \\ Milk-clotting Enzyme Preparation by Aspergillus niger and the Effect of Various Factors on its Activity
}

\author{
By H. G. OSMAN, A. F. ABDEL-FATTAH, M. ABDEL-SAMIE \\ AND SOUHAIR S. MABROUK \\ Laboratory of Microbiological Chemistry, National Research Centre, \\ Dokki, Cairo, U.A.R.
}

\section{(Accepted for publication I5 August 1969)}

\begin{abstract}
SUMMARY
Among 20 locally isolated fungi, Aspergillus niger isolate no. 58 proved to be suitable for the production of active extracellular milk-clotting enzyme. The addition of acetate buffer to the reaction mixture enhanced the clotting of milk by the enzyme whereas citrate + phosphate buffer hindered the process. The general properties of the crude enzyme were studied. Precipitation with ammonium sulphate, ethanol, acetone and tannin showed that ammonium sulphate was unsuitable for precipitation while the other precipitants.produced sufficiently active fractions.
\end{abstract}

\section{INTRODUCTION}

Studies on the production of milk-clotting enzymes from microbial sources have gained interest during the last decade; the production of milk-clotting enzymes by different types of micro-organisms has been reported (Arima \& Iwasaki, 1964; Veselov, Tipograf \& Petina, 1965; Knight, 1966). The increasing demands on rennin for cheese making in Egypt and the prohibition of the slaughter of calves justified a study aiming to search for rennin substitutes from sources other than animals and in particular from micro-organisms.

\section{METHODS}

Micro-organisms. The fungi used in the present work were taken from the fungal collection of the Centre of Cultures of the National Research Centre, Cairo.

Culture media. The following media were used. Medium I: Corn-steep liquor ( $2 \%$, $\mathrm{w} / \mathrm{v})+$ lactose $(\mathrm{I} \%, \mathrm{w} / \mathrm{v})$ in water; Medium 2: Cane black-strap molasses $(\mathrm{I} 2 \%, \mathrm{w} / \mathrm{v})$ in water; Medium 3: Cane black-strap molasses ( $12 \%, w / v)+$ lactose (I \%, w/v) in water; Medium 4: Milk whey alone; Medium 5: Lactose $(2 \%, \mathrm{w} / \mathrm{v})$ in milk whey; Medium 6: A defined medium prepared according to Prill, Wenck \& Peterson (1935) containing (g./1.): glucose, 50; $\mathrm{NH}_{4} \mathrm{NO}_{3}$, Io; $\mathrm{KH}_{2} \mathrm{PO}_{4}, 6 \cdot 8 ; \mathrm{MgSO}_{4} \cdot 7 \mathrm{H}_{2} \mathrm{O}, 5$; $\mathrm{FeCl}_{3} .6 \mathrm{H}_{2} \mathrm{O}, 0 \cdot 16 ; \mathrm{ZnSO}_{4} \cdot 7 \mathrm{H}_{2} \mathrm{O}, 0.05$.

Cultivation. Transfers were made from the stock slants to Dox agar plates which were then incubated at $30^{\circ}$ for 7 days. Two discs $(0.5 \mathrm{~cm}$. diam.) were cut from the 7 -day culture and inoculated into $50 \mathrm{ml}$. sterile medium in $250 \mathrm{ml}$. flat bottomed flasks. Unless otherwise specified, the flasks were incubated for 3 to 4 days at $30^{\circ}$. At the end of the incubation period the culture medium was filtered off and its volume adjusted to $50 \mathrm{ml}$. 
Measurement of milk-clotting activity. The method of Berridge (1952) was used; $2.5 \mathrm{ml}$. of the enzyme sample were incubated with $10 \mathrm{ml}$. reconstituted skim milk ( 2 g. dry skim milk/100 ml. of $0.01 \mathrm{M}-\mathrm{CaCl}_{2}$ ) at $40^{\circ}$ and the clotting time recorded. In the present work, one unit is considered to be the amount of the enzyme in $2.5 \mathrm{ml}$. enzyme preparation which clots $10 \mathrm{ml}$. milk in Io min. at $40^{\circ}$.

Proteolytic activity. The proteolytic activity of the enzyme sample was measured on the basis of the gelatinase test of Bergkvist (1963), who used it for determining the proteolytic activity of proteases produced by Aspergillus oryzae. The gelatinase activity was estimated as the decrease in the relative viscosity of a $5 \%(w / v)$ buffered gelatin solution containing the enzyme (acetate buffer of different $\mathrm{pH}$ values).

Precipitation of milk-clotting enzyme. This was achieved with ammonium sulphate, ethanol, acetone or tannin. With ammonium sulphate, the dialysed solutions of the precipitates and supernatant fluids were adjusted to $\mathrm{pH}_{4}^{\circ} \mathrm{O}$ with acetate buffer. Precipitation with tannin was according to the method of Bergkvist (1963) and the precipitates freed from tannin by repeated dispersal in acetone during centrifugation. Each precipitate was resuspended in $0.02 \mathrm{M}$-acetate buffer $(\mathrm{pH} 4.0)$ and made to a known value with water.

\section{RESULTS}

Examination of the fungal cultures for production of milk-clotting enzyme. Medium I was used for cultivation. Of the 20 fungal cultures tested, surface cultures of Aspergillus niger no. 58 exhibited the highest milk-clotting activity (Table 1 ). The activity was always associated with spore formation. Thus, non-sporulating cultures, no matter how old, did not exhibit milk-clotting activity. Aspergillus niger no. 58 was, therefore, used in the succeeding experiments.

\section{Table I. Survey of fungal cultures for the production of milk-clotting enzyme}

\begin{tabular}{|c|c|c|c|c|c|c|}
\hline \multirow{2}{*}{ Time of incubation (days)...... } & \multicolumn{3}{|c|}{ Surface culture } & \multicolumn{3}{|c|}{ Shaken culture } \\
\hline & \multirow{2}{*}{\multicolumn{6}{|c|}{ Clotting-time of milk (min.) }} \\
\hline Micro-organisms & & & & & & \\
\hline Aspergillus fischeri 108 & -ve & $-\mathrm{ve}$ & 240 & 240 & 240 & 300 \\
\hline A. flavus II2 & 75 & 120 & 240 & 45 & 55 & 180 \\
\hline A. fumigatus 109 & 90 & 180 & $-v e$ & 105 & 180 & $-\mathrm{ve}$ \\
\hline$A$. niger $3 \mathrm{~N}$ & -ve & 35 & 120 & 55 & 30 & 80 \\
\hline A. niger 58 & 15 & 90 & $-v e$ & 105 & 105 & -ve \\
\hline Cunninghamella sp. I 14 & $-v e$ & 300 & 240 & $-\mathrm{ve}$ & 270 & 270 \\
\hline Epicoccum purpurosence 5 & -ve & 40 & 30 & $-v e$ & 30 & 30 \\
\hline Fusarium equiseta 8 & $-\mathrm{ve}$ & 165 & -ve & -ve & - ve & - ve \\
\hline F. oxysporium 6 & -ve & 195 & 300 & -ve & 360 & 240 \\
\hline F. semitectum & $-\mathrm{ve}$ & 45 & $-\mathrm{ve}$ & -ve & -ve & $-\mathrm{ve}$ \\
\hline F. sambucinum 7 & -ve & $-\mathrm{ve}$ & -ve & $-\mathrm{ve}$ & -ve & - ve \\
\hline Geotrichum candidum & - ve & 300 & 360 & -ve & $-\mathrm{ve}$ & $-\mathrm{ve}$ \\
\hline Mucor sp. IOI & - ve & 300 & 180 & -ve & $-\mathrm{ve}$ & -ve \\
\hline Oospora sp. 3 & $-\mathrm{ve}$ & - ve & $-\mathrm{ve}$ & -ve & $-\mathrm{ve}$ & $-v e$ \\
\hline Penicillium chrysogenum 102 & - ve & 90 & 300 & - ve & 180 & 300 \\
\hline$P$. notatum 62 & - ve & -ve & 300 & $-\mathrm{ve}$ & $-\mathrm{ve}$ & -ve \\
\hline P. notatum 105 & - ve & - ve & $-\mathrm{ve}$ & -ve & -ve & -ve \\
\hline P. ochraceus Wilhelm 67 & - ve & 60 & I 80 & -ve & 90 & $-\mathrm{ve}$ \\
\hline Stemiphylium consortiale $2 \mathbf{I}$ & - ve & 210 & 180 & $-\mathrm{ve}$ & 210 & 240 \\
\hline Trichoderma viride 60 & - ve & -ve & 300 & 330 & 360 & 360 \\
\hline
\end{tabular}

-ve: No clotting. 
Suitability of different media for the production of milk-clotting enzyme by Aspergillus niger no. 58. The activity of the milk-clotting enzyme depended on the composition of the medium (Table 2). Undiluted whey medium fulfilled all the requirements for maximum production of enzyme activity. This result was of importance because of the possibility of conducting enzyme production and cheese production in one place. The immediate precipitation in the clotting test brought about by the medium 3 culture filtrate did not denote the presence of milk-clotting enzyme but was probably due to the acidity of the reaction mixture.

Table 2. Production of milk-clotting enzyme by Aspergillus niger 58 in different culture media

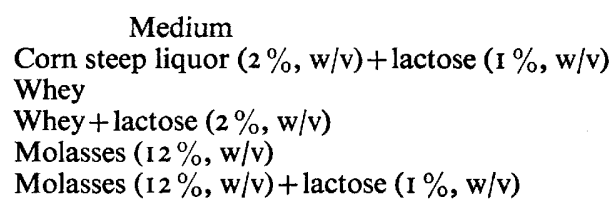

\begin{tabular}{|c|}
\hline $\begin{array}{l}\text { Final } \mathrm{pH} \text { value } \\
\text { of culture } \\
\text { filtrate }\end{array}$ \\
\hline 3.7 \\
\hline $2 \cdot 5$ \\
\hline 3.0 \\
\hline $4^{\circ} 0$ \\
\hline 2.5 \\
\hline
\end{tabular}

Table 3. Effect of buffers on milk-clotting activity of Aspergillus enzyme

$\begin{array}{lccc}\text { Buffer } & \begin{array}{c}\text { pH value } \\ \text { of buffer }\end{array} & \begin{array}{c}\text { pH value } \\ \text { of reaction } \\ \text { mixture }\end{array} & \begin{array}{c}\text { Clotting-time of } \\ \text { reaction mixture } \\ \text { (min.) }\end{array} \\ \text { Acetate } & 5 \cdot 0 & 6 \cdot 0 & 1 \cdot 92 \\ & 5 \cdot 2 & 6 \cdot 0 & 3 \cdot 08 \\ & 5 \cdot 4 & 6 \cdot 2 & 3 \cdot 66 \\ 5 \cdot 6 & 6 \cdot 3 & 10 \cdot 83 \\ & 5 \cdot 9 & 6 \cdot 4 & 18 \cdot 75 \\ \text { Clotting-time of control }: 45 \text { min. } & & \\ \text { McIlvaine } & 5 \cdot 2 & 6 \cdot 0 & 75 \cdot 00 \\ & 5 \cdot 4 & 6 \cdot 0 & 75 \cdot 00 \\ & 5 \cdot 6 & 6 \cdot 0 & \text { no clotting } \\ & 5 \cdot 8 & 6 \cdot 1 & \text { no clotting }\end{array}$

Clotting-time of control: $25 \mathrm{~min}$.

In spite of the low $\mathrm{pH}$ values and the formation of good mycelial growth obtained with Aspergillus niger no. 58 grown on the defined medium no. 6, no milk-clotting activity was detected in the culture filtrate. Cultures which did not produce spores did not show any milk-clotting activity in the culture filtrates. Some relationship seems to exist between the formation of spores and the production of milk-clotting enzymes.

Effect of buffers on milk-clotting activity of Aspergillus niger no. $5^{8}$ culture filtrates. In this experiment and the succeeding ones medium I was used for growth. The buffers tested were acetate and McIlvaine citrate + phosphate buffers at different $\mathrm{pH}$ values. The clotting of milk by the Aspergillus enzyme was accelerated by calcium ions, and retarded by citrate + phosphate, presumably owing to the combination with calcium (Table 3).

The influence of various factors on milk-clotting activity of Aspergillus niger no. $5^{8}$ culture filtrate. The age of the culture was found to influence markedly the milk- 
clotting activity. The 3-day culture filtrate of $A$. niger no. 58 gave the highest activity. The mycelial mats were completely sporulated at that stage of growth. After the third day of incubation, gradual loss of activity occurred accompanied by an increase in $\mathrm{pH}$ value of the culture.

As regards the effect of enzyme concentration, it was found that the smaller amounts of enzyme were being destroyed in the milk and that the larger amounts were to some extent inhibited, possibly as a result of slowness in the second phase of clotting.

The milk-clotting activity was optimal at $52^{\circ}$; such a high optimal temperature is normal for microbial milk-clotting enzymes (Tsugo et al. 1964). The effect of heat on the crude enzyme preparation indicated that the enzyme was thermolabile; it was inactivated when heated at $60^{\circ}$ for $30 \mathrm{~min}$. This result is in accordance with that obtained by other investigators for a microbial clotting enzyme which is thus relatively more heat resistant than are commercial rennet preparations (Tsugo et al. 1964). At $53^{\circ}$ the crude enzyme retained its full activity when heated for $15 \mathrm{~min}$. although, at the same temperature, a loss of activity of about $20 \%$ occurred when the enzyme was left to react with milk without preheating. This latter phenomenon may be attributed to the loss of $\mathrm{CO}_{2}$ from the milk, causing the $\mathrm{pH}$ value to increase.

Table 4. Proteolytic (gelatinase) activity of the crude milk-clotting enzyme from Aspergillus niger 58 culture filtrate

\begin{tabular}{|c|c|c|c|c|c|c|c|}
\hline \multirow{2}{*}{$\begin{array}{l}\mathrm{pH} \text { value of } \\
\text { reaction } \\
\text { mixture }\end{array}$} & \multicolumn{7}{|c|}{ Digestion periods (min.) } \\
\hline & $5 \cdot 0$ & 15 & $\begin{array}{c}30 \\
\% \mathrm{Dec}\end{array}$ & $\begin{array}{l}45 \\
\text { in relat }\end{array}$ & $\begin{array}{l}60 \\
\text { cosity }\end{array}$ & 90 & I 20 \\
\hline $3 \cdot 40$ & $17 \cdot 00$ & $22 \cdot 03$ & $26 \cdot 00$ & $26 \cdot 00$ & $29 \cdot 37$ & $34 \cdot 00$ & $35 \cdot 59$ \\
\hline $4 \cdot 05$ & $17 \cdot 5 \mathrm{I}$ & $24 \cdot 29$ & $27 \cdot$ I I & $29 \cdot 37$ & $29 \cdot 94$ & $34^{\circ} 00$ & $35 \cdot 59$ \\
\hline 4.99 & 18.64 & $23 \cdot 16$ & $25 \cdot 42$ & $27 \cdot$ II & $29 \cdot 37$ & $29 \cdot 94$ & $34: 46$ \\
\hline $5 \cdot 89$ & $2 I \cdot 46$ & $26 \cdot 00$ & $27 \cdot$ II & $29 \cdot 37$ & $29 \cdot 37$ & $29 \cdot 94$ & $32 \cdot 20$ \\
\hline
\end{tabular}

Table 5. The milk-clotting activity of the ethanol precipitates of Aspergillus enzyme preparations

$\begin{array}{llllll}\text { Culture filtrate + ethanol (v/v) } & \mathrm{I}+\mathrm{I} & \mathrm{I}+2 & \mathrm{I}+4 & \mathrm{I}+6 & \mathrm{I}+8 \\ \text { Activity relative to culture } & \mathrm{O} \cdot \mathrm{I} 7 & \mathrm{I} \cdot 4 \mathrm{I} & \mathrm{I} \cdot 22 & \mathrm{I} \cdot 30 & 0 \cdot 90\end{array}$

filtrate (units $/ 2.5 \mathrm{ml}$.)

Table 6. The milk-clotting activity of acetone precipitates of Aspergillus enzyme preparations

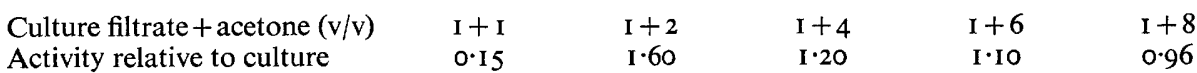

ctivity relative to culture

The gelatinase activity of the culture filtrate indicated a weak proteolytic action (Table 4) as compared with the results presented by Bergkvist (1963) for the proteases of Aspergillus oryzae. The latter author found a significant decrease in the viscosity of gelatin, reaching about $70 \%$ after digestion for only $5 \mathrm{~min}$.

The partial purification of the microbial milk-clotting enzyme by precipitation with some agents indicated that ammonium sulphate was unsuitable since a marked loss of enzyme activity occurred as soon as enough salt to cause precipitation was added. 
Precipitation with ethanol or acetone gave precipitates with good milk-clotting activity; two volumes of either solvent gave the most active precipitates (Tables 5,6). These results are more or less in accordance with those found by Iwasaki, Tamura \& Arima (1967).

Table 7. The effect of tannin concentration on the milk-clotting activity of the precipitates of Aspergillus enzyme preparations from culture filtrate of $\mathrm{pH} 5.5$

$\begin{array}{lllllll}\text { Tannin concentration }(\%, \mathrm{w} / \mathrm{v}) & 0 . \mathrm{I} & 0.3 & 0.5 & 0.7 & 0.9 & \mathrm{I} \cdot 0 \\ \text { Activity relative to culture } & 0.02 & 0.37 & 0.7 \mathrm{I} & 0.83 & \mathrm{I} \cdot 4 & 0.65\end{array}$

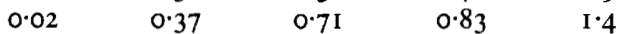

filtrate (units $/ 2.5 \mathrm{ml}$.)

Table 8. The effect of the $p H$ value of the culture filtrate on the milk-clotting activity of precipitates by $0.9 \%(w / v)$ tannin

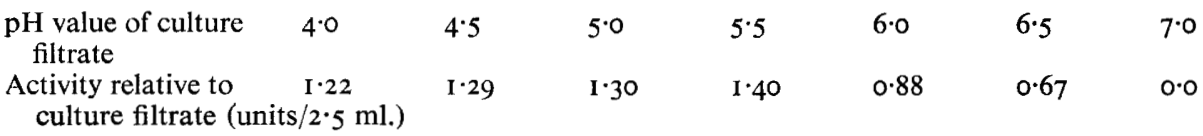

Precipitation with tannin gave active precipitates. The extent of the recovered activity depended on tannin concentration (Table 7) as well as the $\mathrm{pH}$ value of the culture filtrate (Table 8). These results are in accordance with those found by Bergkvist (1963) for the proteolytic enzymes of Aspergillus oryzae.

This paper is dedicated to the memory of the late Professor E. M. Taha, who suggested the topic of this work.

\section{REFERENCES}

ARIMA, K. \& IWASAKI, S. (I964). Milk coagulating enzyme 'microbial rennet' and method of preparation thereof. U.S. Pat. 3,151,039.

Bergkvist, R. (1963). The proteolytic enzymes of Aspergillus oryzae. I. Methods for the estimation and isolation of the proteolytic enzymes. Acta chem. scand. 17, I52 I.

Berridge, N. J. (1952). Some observations on the determination of the activity of rennet. Analyst, Lond. 77, 57.

IwASAKI, S., TAMURA, G. \& ARIMA, K. (1967). Milk clotting enzyme from micro-organisms. II. The enzyme production and the properties of crude enzyme. Agric. biol. Chem. 31, 546 .

Knight, S. G. (1966). Production of a rennin-like enzyme by moulds. Can. J. Microbiol. 12, 420.

Prill, E. A., Wenck, P. R. \& Peterson, W. H. (1935). Factors influencing the amount and nature of the fat produced by Aspergillus fischeri. Biochem. J. 29, $2 \mathrm{I}$.

Tsugo, T., Yoshino, U., Taniguchi, K., Ozawa, A., Miki, Y., Iwasaki, S. \& Arima, K. (I964). Studies on cheese making by using milk clotting enzyme of Mucor pusillus Lindt. I. Rennetic properties of enzyme. Jap. J. zootech. Sci. 35, $22 \mathrm{I}$.

Veselov, I. YA., TIPOGRaPh, D. Ya. \& Petina, T. A. (1965). Aspergillus candidus as a producer of rennin. Prikl. Biokhim. Mikrobiol. r, 52. 